

\section{In this issue:}

Enemies of Books ........317

View from $\mathrm{HQ}$
Relator Terms for Rare Book, Manuscript, and Special Collections Cataloging

Bibliographic Instruction: Library Seminars

\section{Library Organization}

Development at

Northeastern University . . .327

Washington Hotline .......328

News from the Field .......330

People ...............332

Publications .............339

Calendar ...............340

Classified Advertising _......344

College \& Research Libraries News (ISSN 0099-0086) is published by the Association of College and Research Libraries, a division of the American Library Association, as 11 monthly (combining July-August) issues, at $50 \mathrm{E}$. Huron St. Chicago, IL 60611. Annual subscription: \$10. Single copies and back issues, $\$ 3,50$ each. Second-class postage paid for at Chicago, lllinois, and at additional mailing offices.

Editor: George M. Eberhart, ACRLALA, 50 E. Huron St. Chicago IL 60611; (312) 944-6780. President ACRL: David C. Weber, Executive Director, ACRL: Julie Carroll Virgo.

Production and circulation office: $50 \mathrm{E}$. Huron St., Chicago, $1 \mathrm{~L} 60611$. Display advertising should be sent to Leona Swiech. Advertising Traffic Coordinator, ALA, at above address. Send classified ads to ACRL. Change of address and subscription orders should be addressed to College \& Research Libraries News, for receipt at the above address at least two months before the publication date of the effective issue.

Inclusion of an article or advertisement in C\&RL News does not constitute official endorsement by ACRL or ALA

A partial list of the services indexing or abstracting the contents of C\&RL News includes: Current Contents: Social \& Be havior Sciences; Current Index to Journals in Education; Information Science Abstracts; Library \& Information Science Abstracts; Library Literature; and Social Sciences Citation /ndex.

To the postmaster: Please send undeliverable copies to ACRL, 50 E. Huron St., Chicago, IL 60611.

(C) American Library Association 1981. All material in this journat subject to copyright by the American Library Association may be photocopied for the noncommercial purpose of scientific or educational advancement.
Literature has been cut out of the periodical collection in the Undergraduate Library.

By a lucky chance, however, we have been able to demonstrate that the mutilation is not new and not only an Undergraduate Library problem. In 1978 the bound copies of Sports $1 \mathrm{li}$ lustrated were transferred from the Wilson Library Periodicals Department to Undergrad. The next year a donor gave us a second copy of ses: eral volumes. We know that those copies were in perfect condition two years ago. A recent survey of copy ones and copy twos in the 1970 and 1972 volumes reveals:

\section{Mutilations \\ Copy One Copy Two}

1970 (25 issues

examined)

1972 (13 issues

examined)

We can assume from this small sample that mutilation has been occurring for some time and only came to our attention when the damage had accumulated to a certain proportion.

Less noticeably, another kind of damage has been accumulating in the library collections. Books, not so subject to the razor as periodicals, are more subject to underlining and marginal comments. Fifty-three of one hundred Undergraduate Library books surveyed in April had been marked by readers with pencil or pen. Some underlined books eventually are ruined and must be discarded or replaced. Most are merely made esthetically displeasing and distracting to readers. Reading an underlined book is like listening to a scratched or warped record. It becomes hard to concentrate on the original content.

Is the library the victim of teaching methods which inadvertently teach disrespect for books and periodicals? A whole generation of students seems to have been raised clipping pictures from periodicals for elementary school projects. They have also been taught to bring out key ideas with a back hand slash of yellow or pink hi-liner. It is very possible that some students or even faculty members no longer know how to read a page without a pen or pencil in hand to pick out the high spots. They may underline instinctively and thoughtlessly in books that are not their own. The results are the same as if the marks were callously intended to show contempt for all others who must read the volume afterward. No one else can ever read that book as the author wrote it. The underlined phrases will jump out at readers destroying their rhythm and distracting them in their attempts to comprehend the meaning of the words.

Another perplexing problem to the library is the incidence of vandalism. Signs in the Wilson Library stack addition keep disappearing, apparently to take up new residence on dorm room 
walls. Everyone is familiar with the graffiti that grows like a fungus on public rest room walls. That it bloomed as fast and as virulently as it has in the new stack addition is discouraging and surprising.

What is it in human nature that must foul a place it inhabits before it feels comfortable in it? It is the side of humans brought to vivid life by the orcs in J.R.R. Tolkien's Lord of the Ringsthose beings who scarred and destroyed everything they touched, who could be tracked across the countryside by the detritus and filth and broken things they left in a broad trail behind them. Will the people who write in library books and cut the pages or steal the signs be the same ones who leave their beer cans and potato chip bags in Grand Teton National Park?

This orcishness of human beings is an expensive problem to the library, the solution for which the library is still searching. Whatever steps are taken to protect the library buildings,

\section{Brigid Welch \\ ACRL Program Officer}

Editor's Note: Written in response to membership requests, this column features news from $A C R L$ headyuarters and discusses features of the office's operations.

In 1980 and 1981 ACRL initiated two new programs in continuing education and bibliographic instruction. This column summarizes the direction these programs have taken and the plans for their future development, and will point out several ways in which members may become involved.

Continuing education courses at the ALA Annual Conference in San Francisco and at the ACRL National Conference in Minneapolis are among the first steps toward establishment of the long-range program

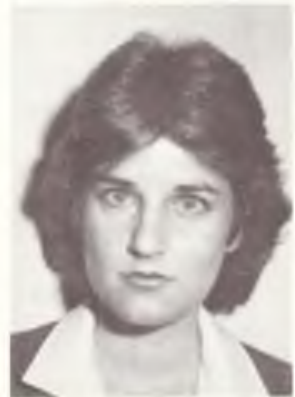

C. Brigid Welch of continuing education mandated by the ACRL Board of Directors in June 1979. The program's goal is to provide quality continuing education at a reasonable cost to ACRL members.

Short, concentrated courses will include topics from the following five subject areas: manage- furnishings, and collections, it appears that more vigilance will be required, more of a public relations effort will be necessary, and that penalties for culprits will need to be strictly enforced. It is also undoubtedly true that an indignant, angry faculty and student body will be the libraries' best allies in the fight against the enemies of books.

${ }^{1}$ Clyde Hendrick \& Marjorie Murfin, "Project Library Ripoff: A Study of Periodical Mutilation in a University Library," College \& Research Libraries 35 (1974): 402-11. See also Dana Weiss, "Book Theft and Book Mutilation in a Large Urban University Library," College \& Research Libraries, 42 (1981): 341-47.

Editor's Note: This contribution originally appeared in the May, 1981, issue of Library Notes, published by the University of North Carolina Library, Chapel Hill.

\section{The View from HQ}

ment, library skills, technology update, the academic environment, and professional development. These short courses (one to two days in length) will feature an intensive treatment of a particular topic, thus enabling the participants to gain more than an overview of the subject. In order to facilitate and enhance the educational experience of the participants, courses will build upon one another, enrollment will be kept low (35 registrants maximum), and specific levels of background and experience will be required.

A proven means of providing quality, costeffective continuing education, the Medical $\mathrm{Li}$ brary Association's continuing education program has been adopted as ACRL's model. The ACRL continuing education program will utilize, like MLA's program, standardized instructional materials - course outlines and exercises, syllabi, bibliographies-for each course. ACRL will contract with qualified course designers to develop the instructional materials; a network of instructors at the national and regional level will be asked to teach the courses. This approach reduces the design costs frequently incurred with each continuing education course offering and at the same time increases the accessibility of the courses to ACRL members

Current work on the continuing education program's development includes identification of qualified course designers as well as instructors from the academic library and information science community. Planning is underway for courses to be offered prior to the ALA Annual Conference in Philadelphia. Proposed topics include writing 